\title{
A ESTRUTURA FUNDIÁRIA DO MUNICIPIO DE SANTA MARIA
}

Sērgio Augusto Carvalho Bernardes, Ivo Lauro Müller Filho e Clady Teresinha Lopes

Departamento de Geociências. Centro de Ciências Naturais e Exatas. UFSM. Santa Maria, RS.

Silsomar Flores Adaime

Departamento de Física. Centro de Ciências Naturais e Exatas. UFSM. Santa Maria, RS.

RESUMO

Os autores enfocam a malha fundiāria do municīpio de Santa Maria, no Rio Grande do Sul, sob dois aspectos: ligados à posse e à dimensão.

Em um primeiro momento, estudam o número de propriedades ru rais, considerando um intervalo temporal de 15 anos. Analisam, no pe rỉodo, o comportamento das propriedades por grupos de ārea, consta tando principalmente o aumento significativo do seu número no grupo com menos de 100 ha e as razões da pulverização fundiāria, ao mesmo tempo em que buscam causas para explicar a partição de propriedades, de forma generalizada em qualquer dos grupos dimensionais.

No segundo momento, buscam atravēs do Coeficiente de Gini, estabelecer o nịvel de concentração da posse da terra. A concentra ção forte a muito forte constatada, carece de importāncia, frente à anālise das paisagens por distrito. Fica evidente que, considerando as condições físicas, no atual estāgio de desenvolvimento regional, pode ser mais desejāvel a concentração, a uma pulverização desestị mulante e geradora de êxodo rural.

\section{SUMMARY}

BERNARDES, S.A.C.; MÜLLER FILHO, I.L.; LOPES, C.T. and ADAIME, S.F. 198.8. Rural land ownership in Santa Maria municipality. Ciência e Natura, 10:59-87.

The authors focus on land ownership distribution of Santa Maria municipality, in the state of Rio Grande do Sul, under two aspects: possession and dimension.

At first instance, the authors observe the number of rural properties considering intervals of 15 years. Activity and property size are analyzed noting primarily the significant increase in the number of properties with less than 100 ha and the causes of land pulverization, while at the same time the authors search for a cause to explain property division in a general way amongst any of the dimensional groups.

Secondly, the level of concentration of land ownership is made by using the Gini Coefficient. The high to very high concentration found, lacks significance, considering the analysis of the district's 
landscape. Consequently it is obvious that considering the physical conditions at the present stage of regional development, the concentration can be much more important than the unestimulating pulverization which is alds a cause of rural exodus.

INTRODUÇAO

0 grupo de pesquisa envolvido no presente trabalho, jā de muitos anos acompanha a evolução do espaço rural do Município, no to cante não só a sua evolução produtiva, como tambēm as transformações de sua malha fundiāria (Figura 1 ).

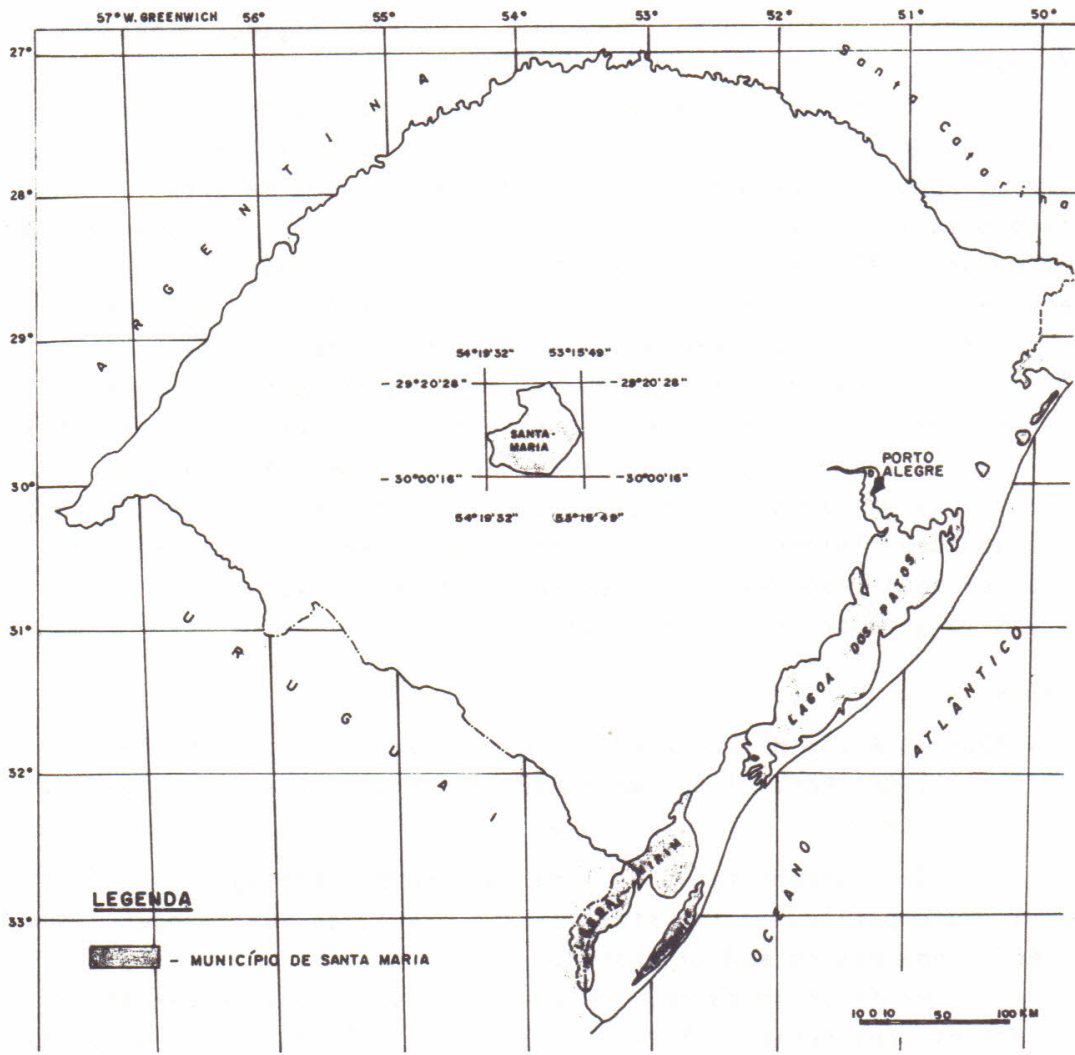

Figura 1 - Localização da ārea de estudo.

E na busca de detalhamento do comportamento do Municipio, quanto ao aspecto propriedade da terra, que os pesquisadores se de tém, encontrando fortes razões para, no atual momento.de questiona. mentos económico-sociais, fornecer subsỉdios que facilitem anālises e tomadas de decisões não equivocadas, ou simplesmente comprometidas com estruturas transformadoras, porém utópicas, certamente geradoras de frustrações, quem sabe desestabilizadoras de um equilibrio fundiārio 
conquistado em séculos de histōria.

Os governantes, nas ūltimas dēcadas, buscam fōrmulas capa zes de responder inquietações sociais, que em forma de pressão nas cida das periferias urbanas, desequilibram crescentemente a qualida de de vida nos espaços urbanizados, tanto mais atraentes sejam.

E o problema urbano que se avoluma e desestabiliza a har monia da convivencia nas cidades, que se tornam a cada dia mais di ficeis de serem moradas mas que, apesar ou por causa dos desniveis cidade/campo, continuam estimulando a inchação urbana, em especial dos grandes centros: a explosão industrial brasileira, desde a se gunda metade de nosso século, vê um Brasil que foi rural, urbanizan do sua população num ritmo desigual, considerando a capacidade de contenção-assimilação dos fluxos migratórios, na direção dos quadros urbanos mais qualificados.

Não foi apenas a industrialização que fez as cidades cres cerem, em detrimento da concentração demogrä́fica rural. Desenvolve ram-se polos urbanos regionais, que, mesmo não tendo expressão in dustrial, tinham-na cultural ou comercial. Tais polos também colabo raram para o crescimento urbano desequilibrado, a par do esvaziamen to das äreas rurais, cada vez mais tecnificadas e seguramente menos atrativas para os desfavorecidos da fortuna, que dependem do fruto de seu trabalho.

E o caso do municipio de Santa Maria e de sua sede. A ci dade é um polo regional essencialmente terciārio, e o Municīpio é um espelho, em escala reduzida, da realidade fundiāria do estado do Rio Grande do Sul, onde se tangenciam (ainda) sem conflitos, a gran de, a média e a pequena explotação rural, mas também onde se eviden cia desde muitos anos (1960), a invasão das áreas rurais pela explo ração imobiliāria urbana.

Quando foi analisada a estrutura fundiāria do município de Santa Maria (BERNARDES, 1972), o trabalho foi baseado no cadastro da Associação Rural de Santa Maria, e a preocupação ficou centrada em anālise simples de grupos de propriedades classificadas por ärea, pois que, o objetivo do trabalho, era divulgar uma noticia sobre a malha de propriedades rurais do Municipio. Hoje, transcorridos 15 anos e voltados sobre a mesma fonte primāria, iremos traçar um para lelo entre os mesmos grupos de propriedades, para verificar o com portamento da dinâmica da propriedade da terra rural, sobre a super fície do Municipio.

Todavia, nosso projeto se amplia e buscamos uma anālise mais profunda, não só da propriedade, mas principalmente das conse quências do seu uso. Numa primeira etapa, analisaremos a distribuj ção fundiāria, levando em consideração os grupos de propriedades estabelecidas por dimensão, sem vinculā-los a nenhuma idéia de grandeza, pois os termos: 
pequena, média e grande, guardam profunda relatividade e não tradu zem a idéia de função, que no presente estudo é fundamental. Outros sim, iremos acoplar à idéia de espaço físico (quantidade), a idéia de qualidade, onde estarão presentes elementos topogrāficos e geolō gicos do todo espacial do Municipio.

A simples distribuição fundiāria, permitirā, aplicado o Coeficiente de Gini, a determinação do grau de concentração, o que em si nada representará, se efetivamente não medirmos as qualidades envolvidas nos diversos compartimentos físicos do Municipio.

A anālise da realidade fundiāria santamariense, fundamen ta-se em um processo de amostragem, dada a dificuldade de acesso aos dados coletados pelo INCRA (bem como, dada também, sua falta de cre dibilidade). A amostra, levantada nos registros da Associação Rural de Santa Maria, totalizou 1.300 casos em 1987 (541 em 1972). Dos 1.300 estabelecimentos registrados na Associação Rural, como perten centes a proprietārios rurais, os autores selecionaram 771, em fun ção da necessidade de poder localizá-los no espaço santamariense, pa ra mais adequadamente interpretar as interações produção agrāria-es paço geográfico. O tamanho da amostra, de 771 estabelecimentos, é es tatisticamente adequado (GERARDI \& SILVA, 1981:20).

PERCENTAGEM DE PROPRIEDADES SEgUNDO GRUPOS DE AREA, NO INTERVALO DE $1972 / 1987$.

Utilizando cadastro da Associação Rural de Santa Maria', e fiéis ao elaborado a quinze anos atrās, obtivemos uma tabela percen tual das propriedades rurais por grupos de ārea, onde, em critērio meramente local e sem sustentação cientĩfica, ficaram estabelecidas 4 categorias dimensionais.

A Tabela I analisada, no somatōrio dos grupos, apresenta resultados para 1972, que sintetizamos assim:

TABELA I - PERCENTAGEM DE PROPRIEDADES POR GRUPO DE AREA - 1972.

GRUPOS DE PROPRIEDADES

\% DOS GRUPOS NA AMOSTRA

\begin{tabular}{lrr}
\hline GRUPO & I - 0 a 99 ha & $57,42 \%$ \\
GRUPO II - 100 a 499 ha & $22,80 \%$ \\
GRUPO III - 500 a 1.999 ha & $14,69 \%$ \\
GRUPO IV - 2.000 e mais ha & $5,09 \%$ \\
\hline
\end{tabular}

1 Entidade que, com mais de meio sēculo de existēncia, congrega rura listas de todas as atividades primärias do Rio Grande do Sul, inde pendentemente de potencial ou potencialidade economica de prodū ção. 
Do resultado da Tabela I, podemos inferir que hā uma gran de pulverização da propriedade, sem contudo deixar de existir uma concentração da propriedade da terra, pois que uma superfīcie cons $\underline{i}$ derāvel do Municīpio era, em 1972, detida por um nümero pequeno de proprietārios.

0 retorno ao mesmo cadastro, permitiu a visão da dinamici dade da malha fundiāria no tocante a posse, num periodo igual a 15 anos.

A Tabela II a seguir, tambēm analisada no somatōrio dos grupos, mantidos os intervalos, apontou significativas alterações, como é possivel visualizar na sîntese:

TABELA II - PERCENTAGEM DE PROPRIEDADES POR GRUPO DE AREA - 1987.

\begin{tabular}{lcc}
\hline GRUPOS DE PROPRIEDADES & $\%$ DOS GRUPOS NA AMOSTRA \\
\hline GRUPO I -0 a 99 ha & $65,74 \%$ \\
GRUP0 II -100 a 499 ha & $24,74 \%$ \\
GRUPO III -500 a 1.999 ha & $8,70 \%$ \\
GRUPO IV -2.000 e mais ha & $0,78 \%$ \\
\hline
\end{tabular}

A Tabela III abaixo, permite comparar as variações no pe rỉodo (1972/1987):

TABELA III - COMPARATIVO DA \% DE PROPRIEDADES POR GRUPOS DE AREA $1972 / 1987$.

GRUPOS DE PROPRIEDADES

$\%$ DOS GRUPOS NA AMOSTRA

\begin{tabular}{lcccc} 
& & 1972 & 1987 & \\
\hline GRUPO I - 0 a 99 ha & $57,42 \%$ & $65,74 \%$ & $+8,32 \%$ \\
GRUPO II - 100 a 499 ha & $22,80 \%$ & $24,74 \%$ & $+1,94 \%$ \\
GRUPO III - 500 a 1.999 ha & $14,69 \%$ & $8,70 \%$ & $-5,99 \%$ \\
GRUPO IV - 2.000 e mais ha & $5,09 \%$ & $0,78 \%$ & $-4,31 \%$ \\
\hline
\end{tabular}

Apenas considerando o quadro sintese, podemos observar que a malha fundiāria do municīpio de Santa Maria, sofreu significativas alterações no transcurso do período considerado.

As propriedades ditas pequenas e enquadradas no Grupo I (0 a 99 ha - com intervalos de 25 ha), foram fortemente aumentadas, recebendo um incremento de $8,32 \%$. Desta forma, hoje sobre o univer so do espaço rural de Santa Maria, este grupo representa $65,74 \%$ do total das 3.879 propriedades cadastradas pelo INCRA. 
Buscar as razões desta partição aparentemente exagerada, $\bar{e}$ tema de futura pesquisa. Neste trabalho, apenas levantamos algumas hipöteses:

- a melhoria e abertura de rodovias modernas, pavimenta das, criou condições por mutilação de propriedades e por facilidade de acesso ao centro urbano, com comando regional, de geração de inú meras āreas novas, com atividade primária voltada para o consumo ime diato da grande população urbanizada. Nesta hipótese, resultado da observação de campo, é possỉvel perceber a ampliação do anel hortifrutigranjeiro e da bacia leiteira, principalmente motivados por no vos traçados rodoviärios envolventes do quadro urbano;

- a população fortemente terciāria, gera uma qualidade de vida crescente para uma classe mēdia alta, que busca ao longo das rodovias, pequenas chācaras, que embora possuam baixa produção, des tinam-se funcionalmente ao lazer, principalmente ao longo do Rebor do/Transição para o Planalto Vulcānico, onde o recortado da drenagem encaixada fortemente, permite a designação de "Serra".

Considerando a Tabela I, podemos observar que o percen tual de crescimento maior no Grupo I, é correspondente ao sub-grupo "1 a 24 ha", que aumentou em 5,8\% no periodo, conforme a Tabela IV.

Hoje, a malha fundiāria de Santa Maria, apresenta sobre o total das propriedades, o expressivo nūmero de 1.232 pequenos lotes, cuja ārea oscila entre 1 e 24 ha. Claro estā, que além das hipōteses acima. levantadas, precisamos agregar a bāsica e natural partição por direito de herança. Mesmo esta natural partição, favorece as hipōte ses anteriores, pois que a falta de expressão espacial, gera o des conforto de produção. Como o Grupo I determina um tipo de produtor de baixo potencial econōmico, a agregação por compra entre herdeiros é baixa. Não acontece pois, por esta via, a reintegração da proprie dade quanto a seu espaço original.

A Tabela III nos permite observar, que a partir do Grupo III, que abriga as propriedades de 500 a 1.999 ha, ocorre uma sensi vel diminuição no nūmero de propriedades. Esta diminuição ē de $5.99 \%$ sobre a situação de 15 anos atrās. A mais expressiva diminuição, es tā no entanto no ū 1 timo grupo (grandes propriedades que possuem ārea de 2.000 a mais ha), visto que perderam 4,31 pontos percentuais no intervalo temporal do estudo.

Permitimo-nos algumas conclusões, que podemos afirmar vá lidas para o universo rural santamariense e sul-rio-grandense:

1. Qualquer imóvel rural (propriedade) tende à partição:

- por direito de sucessão (entre meeiro e/ou herdeiros);

- por venda pelos herdeiros que não se radicam no campo, ou não se interessam pela produção agropastoril (na realidade, pela 
falta de estimulos em permanecer na atividade rural);

TABELA IV - COMPARATIVO DE PERCENTAGEM DE PROPRIEDADES POR GRUPOS E SUBGRUPOS DE AREA - $1972 / 1987$.

\begin{tabular}{|c|c|c|c|c|c|}
\hline GRUPO DE PROPRIEDADES/HA & $\begin{array}{c}\text { SUB-GRUPOS } \\
\text { CONTIDOS }\end{array}$ & $\begin{array}{c}\text { \% DOS GRUPOS } \\
1972\end{array}$ & $\begin{array}{l}\text { NA AMOSTRA } \\
1987\end{array}$ & $\begin{array}{l}\text { VARIAÇAO NO } \\
\text { PERIODO }\end{array}$ & OBSERVAÇOES \\
\hline \multirow{5}{*}{$\begin{array}{l}\text { GRUPO I - Propriedades } \\
\text { de } 1 \text { a } 99 \text { ha }\end{array}$} & $1-24$ & 25,98 & 31,78 & $+5,80$ & \multirow{5}{*}{$\begin{array}{l}\text { GRUPO I - } \\
\text { Intervalo } \\
\text { de } 25 \text { ha }\end{array}$} \\
\hline & $25-49$ & 16,19 & 19,06 & $+2,87$ & \\
\hline & $50-74$ & $\quad 9,98$ & 9,98 & nula & \\
\hline & $75-99$ & 5,27 & 4,92 & $-0,35$ & \\
\hline & & 57,42 & 65,74 & $+8,32$ & \\
\hline \multirow{9}{*}{$\begin{array}{l}\text { GRUPO II - Propriedades } \\
\text { de } 100 \text { a } 499 \text { ha }\end{array}$} & $100-149$ & 4,83 & 7,52 & $+2,69$ & \multirow{9}{*}{$\begin{array}{l}\text { GRUPO II - } \\
\text { Intervalo } \\
\text { de } 50 \text { ha }\end{array}$} \\
\hline & $150-199$ & 5,27 & 4,53 & $-0,74$ & \\
\hline & $200-249$ & 3,75 & 3,24 & $-0,51$ & \\
\hline & $250-299$ & 1,88 & 2,99 & $+1,11$ & \\
\hline & $300-349$ & 2,07 & 2,33 & $+0,26$ & \\
\hline & $350-399$ & 1,60 & 1,03 & $-0,57$ & \\
\hline & $400-449$ & 2,44 & 2,07 & $-0,37$ & \\
\hline & $450-499$ & 0,96 & 1,03 & $+0,07$ & \\
\hline & . & 22,80 & 24,74 & $+1,94$ & \\
\hline & $500-599$ & 2,07 & 1,43 & $-0,64$ & \multirow{5}{*}{$\begin{array}{l}\text { GRUPO III - } \\
\text { Intervalo } \\
\text { de } 100 \text { ha }\end{array}$} \\
\hline & $600-699$ & 2,82 & 0,90 & $-1,92$ & \\
\hline & $700-799$ & 0,96 & 1,30 & $+0,34$ & \\
\hline & $800-899$ & 2,07 & 1,43 & $-0,64$ & \\
\hline & $900-999$ & 1,69 & 1,55 & $-0,14$ & \\
\hline & & & & & \multirow[t]{4}{*}{$\begin{array}{l}\text { Intervalo } \\
\text { de } 500 \text { ha }\end{array}$} \\
\hline & $1000-1499$ & 3,20 & 1,82 & $-1,38$ & \\
\hline GRUPO II I - Propriedades & $1500-1999$ & 1,88 & 0,27 & $-1,61$ & \\
\hline \multirow[t]{4}{*}{ de 500 a 1.999 ha } & & 14,69 & 8,70 & $-5,99$ & \\
\hline & $2000-2999$ & 2,07 & 0,39 & $-1,68$ & \multirow{5}{*}{$\begin{array}{l}\text { GRUPO IV - } \\
\text { Intervalo } \\
\text { de } 1000 \text { ha }\end{array}$} \\
\hline & $3000-3999$ & 1,69 & 0,13 & $-1,56$ & \\
\hline & $4000-4999$ & 0,96 & 0,13 & $-0,83$ & \\
\hline GRUPO IV - Propriedades & +5000 & 0,37 & $0,13:$ & $-0,24$ & \\
\hline de +2000 ha & & 5,09 & 0,78 & $-4,31$ & \\
\hline
\end{tabular}

E associando-se a esta:

- O envelhecimento dos proprietārios, que não tem quem Thes suceda nas lides rurais e vendem a terra para morrer na cidade, junto aos filhos que migraram antes... (há variantes sócio-culturais interessantes no Rio Grande do Sul, sobre esta realidade);

2. 0 dominio espacial da grande propriedade ainda é exten so (haja visto o da Campanha), mas ele tem diminuido de maneira fla grante, pelos mesmos motivos acima arrolados; 
3. Correlaciona-se o processo jā antigo de descapitaliza ção do campo (leia-se do produtor rural) que se, teoricamente não impede, na prātica dificulta ao extremo o remembramento de uma pro priedade partilhada por herança, quando um ou mais de um dos herdei ros quer comprar as parcelas dos demais, mas não o consegue não só por falta de recursos correspondentes ao valor da terra, mas também por falta de um Fundo (oficial ou privado), que lhe facilite a ob tenção de financiamento para efetivar a compra dos demais herdeiros interessados em vender. Tal falta de capital, aflige tanto o peque no quanto o grande produtor (proprietārio ou não), exceto quando vin culado à grande indústria ou ao alto comércio;

4. As propriedades pequenas sofrem a mesma tendēncia de partição, porém com o agravante do exagero, gerador do "desespero espacial", consequente desestímulo para continuidade da atividade produtora. Decorrem desta situação minifundiāria, ao menos uma das seguintes consequências:

a. Exodo rural;

b. Venda da terra, quase sempre para compradores não da mesma região, ou venda da terra e formação consequente de chácaras de lazer;

c. Abandono da terra, sem venda;

d. A terra improdutiva, serve como local de residencia e o proprie tārio é um empregado sazonal. A propriedade transforma-se em empório de mão-de-obra para os picos agrícolas, ou de serviços especiais das propriedades maiores;

e. Expansão (e exploração) imobiliāria urbana: loteamentos.

A MALHA FUNDIĀRIA POR DISTRITO

0 municipio de Santa Maria, com $3.462 \mathrm{~km}^{2}$, é politicamen te dividido em 9 sub-unidades administrativas (distritos), que obe decem a ordem de 10 a 90 e possuem a seguinte designação e ārea:

10 Sede .............................. $173 \mathrm{~km}^{2}$

20 Dilermando de Aguiar ............ $582 \mathrm{~km}^{2}$

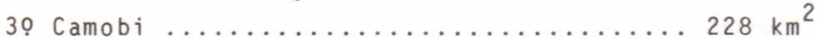

4 o Silveira Martins ................ $190 \mathrm{~km}^{2}$

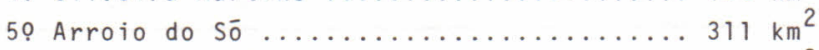

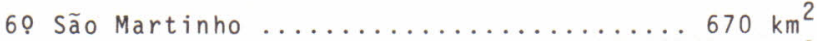

70 Boca do Monte ............... $468 \mathrm{~km}^{2}$

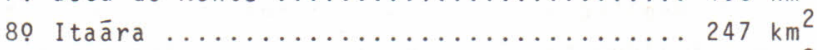

90 Santa Flora ........................... $593 \mathrm{~km}^{2}$

Considerando a geomorfologia do todo deste Município"core" do Rio Grande do Sul, podemos afirmar que suas paisagens representam duas grandes regiões geológicas do Estado: Derrame de Lavas e De pressão Periférica.

No Derrame de Lavas, predominam as rochas vulcānicas, representadas 
nos derrames que mais o capeiam pelo riolito (granōfiro), rochas āci das de grande dureza e baixa decomposição, como testemunhas de um dos ūitimos afloramentos magmáticos juro-cretássicos. Tal estrutura geológica gera um relevo que podemos diferenciar em dois comparti mentos decisivos, quanto à ocupação posterior.

0 primeiro compartimento desta unidade, designaremos de Topo do Planalto, onde as feições de relevo apresentam amplos inter flūvios com coxilhas e patamares suaves interrompidos em sua harmo nia, por morretes geralmente de afloramentos rochosos, ou apenas es parsamente revestidos de vegetação mais pobre e mais lenhosa. A a I timetria indica um planalto de altitude média de 400 metros, com co tas māximas em 500. Alguns aspectos fisionōmicos dos patamares, que se alternam com as coxilhas clássicas, são mantidos por lateritas em nīveis de sustentação. O solo consequente, ācido, è muito instā vel quanto a profundidade, sendo de maneira geral, solos rasos e mui to litossolo que inibem uma agricultura intensamente organizada so bre os grandes espaços, mesmo aqueles raros, cujas classes de solo (declividade), permitiram satisfatōria ocupação agrīcola até alta mente mecanizada.

A vegetação ē rasteira com marcante presença da "barba de bode" (aristida pallens), de baixo valur e indicadora de acidez do minante. As graminneas nobres nativas, coexistem com algumas legumi nosas: trevos rasteiros (trifolium riograndense e polimorfus) e pe ga-pega (desmodium spp.).

Algumas ilhas florestais chamadas "capões", surgem ora no relevo mais encaixado, ora no alto de algumas coxilhas, originando cursos d'água, vertentes e afloramentos do nīvel freático, gerado res de uma exuberante manifestação florestal, onde as espécies tỉp $\underline{i}$ cas da floresta atlântica estão presentes. Os pequenos, inúmeros e rápidos cursos d'água, denominados lajeados, sempre ornados com ma ta galeria, onde o domīnio das espécies pobres e "brancas", determi nam uma manifestação florestal de baixo ou nenhum sentido econômi co-madeireiro.

Este ambiente fïsico suscintamente descrito, situa-se no norte do Municipio e abarca quase que a totalidade dos distritos de Silveira Martins, São Martinho e Itaāra, respectivamente 40, 60 e 80 distrito e parcela considerāvel de Camobi, 30 distrito $(35,26 \%$ do todo da àrea municipal).

Afirmamos que abarca quase a totalidade, pois que $\bar{e}$ indispen sável alertarmos para uma área geomorfológica de transição, que é uma espécie de sub-compartimento do Derrame de Lavas, que chamaremos de Rebordo. A indicação Rebordo, marca o fim do espaço vulcânico e a passagem para a Depressão Central, perifērica a estes derrames e ao Escudo mais ao Sul-Sudeste do Estado, razão de qualificá-la como 
ārea de transição. Nesta porção, ainda não definida em termos de ex tensão superficial, a paisagem sofre profundas modificações, prin cipalmente em função das drenagens profundas dos rios Torooi, Ibi cuj-Mirim, VacacaīMirim, que por estarem com seus nascedouros no Topc do Planalto, deslocam sua ação de modelagem em direção à plani cie periférica, respeitado o divisor d'āgua, para a bacia do Ibicuī-Uruguai ou Jacui-Guaiba.

Quanto à ceologia do Rebordo, è possivel observar que o entalhamento dos rios permitiu, ultrapassada a camada vulcánica de granōfiros, atingir derrames mais antigos e basālticos, onde a mi gração dos leitos gerou terraços de grande fertilidade, embora espa cialmente pouco significativos em superfície. A exposição do aren to, fez possível a visão de fragmentos do antigo deserto Botucatu em "afloramentos" notāveis, alguns do tipo intertrap.

o grande nümero de pequenos cursos d'āgua tributārios, è responsāvel, no conjunto das bacias, pelo grande entalhamento do Re bordo e justifica a designação local de "Serra". A drenagem, alēm de ser geradora de uma grande compartimentação fĩsica, è tambēm res ponsável por um nível hỉdrico acentuadamente maior que o do Topo e por consequência, essencial para entendermos a manifestação flores tal comum e dominante, em todas as porções do Rebordo.

Claro está que a densa ocupação, tornou rarefeita esta ma nifestação florestal, que é hoje apenas residual nas vertentes de acentuada declividade, com classes de solo 8 . Os espaços menos do brados, apresentam matas secundārias ou manifestações arbustivas (vas souras e chircas), denunciadoras de intensa ocupação agrīcola, hoje em pousio ou abandonadas, com consequente formação de campos, num verdadeiro processo de recuo no optimum de vegetação.

A Depressão Periférica, onde o dominio das coxilhas sua ves recobertas de densa vegetação rasteira è a constante, apresenta um embasamento sedimentar, resỉduo da Bacia do Paranā, apertada nes ta porção do Rio Grande entre o Escudo Sul-rio-grandense e o Planal to Meridional (das Araucārias).

A drenagem, representada no municipio de Santa Maria por dominância da bacia do Jacuỉ, tem nỉtidas diferenças entre os tribu tārios, pois que, enquanto os menos expressivos oriundos do planal to, criam riquezas aluvionais no trecho imediato ao Rebordo, como é - caso do Vacacaî-Mirim, que comanda a drenagem de vasta ārea Leste da Depressão em direção ao Jacuí, com nascente em São Gabriel e en grossado pelo Arenal, o Rio Vacacaí, dito grande, percorre região francamente areno-argilosa, embora gere aluviões significativos, que não são, pela fertilidade, tão úteis quanto os da porção Leste já referida.

E neste ambiente de coxilhas, com predomināncia sedimen tar das formações Santa Maria e Rosārio do Sul e que possui segmentos 
aluviais de significativa expressão, que encontramos os distritos de Dilermando de Aguiar (20), Santa Flora (90)), Arroio do Só (50), gran de parte de Boca do Monte (79), a própria Sede (19) e parte de Camo bi (30). Estes distritos reunidos, representam $2.173 \mathrm{~km}^{2}$ que signi ficam $63,86 \%$ do todo da área municipal.

Sobre este ambiente geográfico, a propriedade rural pos sui ajustamentos diferenciados em ārea e em objetivos de produção, como passaremos a enfocar. Para melhor compreensão, identificaremos generalizadamente, os compartimentos físicos pelas expressões:

- Topo ou Superfície do Planalto Meridional;

- Rebordo do Planalto Meridional;

- Superfície das Coxilhas - Depressão Perifērica;

- Planicies Aluviais Recentes - Depressão Periférica.

10 Distrito: SEDE

Detentor da sede com fato urbano de significação regional expressiva, abriga uma cidade de porte médio, com relevāncia na pres tação de serviços e portanto, com função e vocação terciāria notō ria. São $173 \mathrm{~km}^{2}$ do espaço capitaneado, onde é possivel notar uma vasta ārea periférica ao aglomerado, que, embora prescinda de orga nização espacial, dedica o espaço à produção de consumo imediato à população urbana. Encontram-se aĩ, propriedades rurais mutiladas pe los eixos rodoviārios que cingem o quadro urbano, mas não o contém, pois este em franca expansão, segue as direções do alinhamento das rodovias.

A variação na dimensão da propriedade, é extremamente di nàmica, em consequência do quadro urbano próximo, que sugere a cada iniciativa terciária, profundas alterações no objetivo do uso do es paço. E o caso da presença da Universidade Federal de Santa Maria, que urbanizou rapidamente vasto espaço na direção Leste. Os fatores físicos e os compartimentos fenecem de importāncia, pois que o fato humano (urbano), se sobrepõe como decretador da composição da malha fundiāria do Distrito.

Um percentual de $99,66 \%$ das propriedades, pertence ao Gru po I: $(0$ - 99 ha) e neste, é significativo observar, que $83,3 \%$ das propriedades rurais, estão no sub-grupo $0-25$ ha. Tal fato identi fica uma pulverização da terra, que na posição do lọ Distrito, não é globalmente preocupante, pois que a função do espaço é muito mais especulativa no setor imobiliārio (novos e constantes loteamentos), do que na esfera da produção primäria, mesmo a tỉpica do cinturão verde. As atividades de produção rural, existem como uma forma de ocupação residual e estão como que aguardando o momento seguinte de novas iniciativas, governamentais ou não, que ditarão direções da expansão urbana consequente e quase nunca planejada ou, quando o sendo, não obedecida (é o caso do Distrito Industrial). 


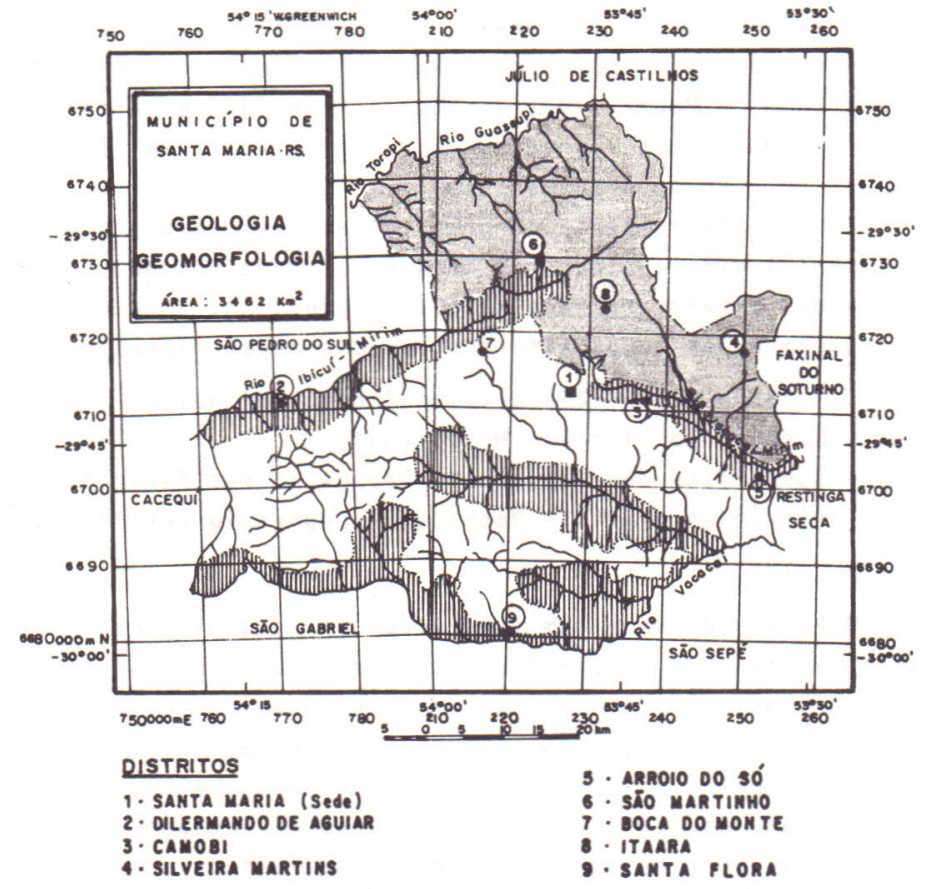

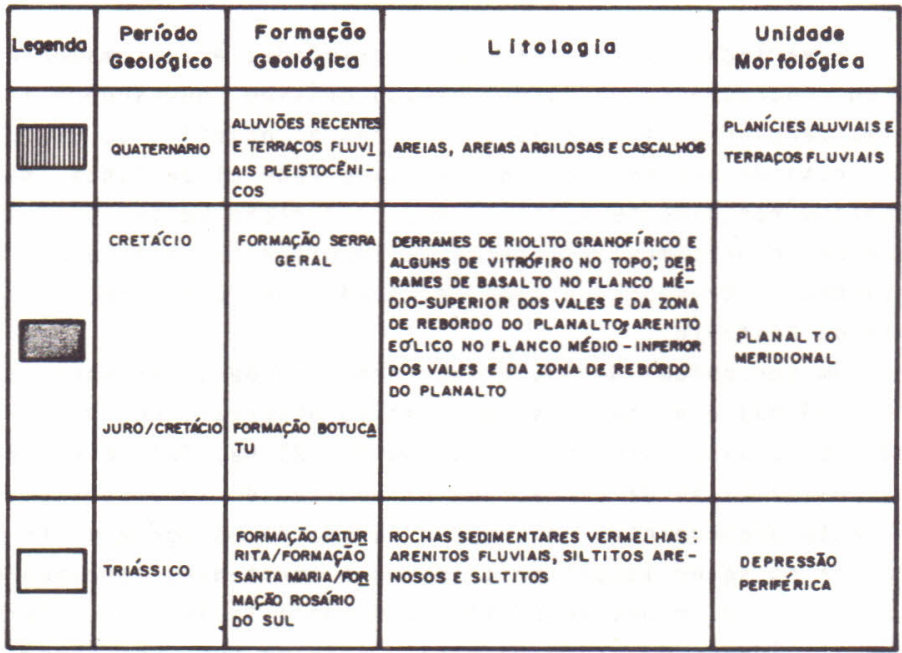

MAPA I - Esboço Geológico-Geomorfológico do Municỉpio de Santa Maria-RS.

\section{Distrito - DILERMANDO DE AGUIAR}

Dilermando de Aguiar, com $582 \mathrm{~km}^{2}$ de superfície, representa 
$16,81 \%$ da ārea total do Municīpio. Predominam coxilhas da Depressão, apresentando importantes āreas aluvionais, principalmente nas cabe ceiras do Banhado de Santa Catarina.

A malha fundiāria segue a regra dominante, pois as proprie dades rurais serão tanto menores, quanto maior a fertilidade dos so los e consequentemente mais agricolas. As coxilhas, dominio de so los mais arenosos e argilosos (solos argilosos da Formação Rosārio do Sul, que facilmente, quando submetidos a agressão agrỉcola, se desestruturam), destinam-se à pecuāria de corte, onde os espaços maio res do todo, e a rentabilidade da atividade, determinam proprieda des maiores.

Assim podemos afirmar, que $40 \%$ da posse da terra, estā en tre as propriedades com 200 ha e mais, sendo este o Distrito que de tém as maiores propriedades do Municipio.

Um dos condicionantes da malha fundiāria, é seguramente o tipo de solo e neste particular, o Distrito confirma, considerando os adensamentos populacionais que se concentram exatamente nos inter flūvios mais ricos, com o surgimento de aglomerados e a prōpria vi la sede.

30 Distrito - CAMOBI

Antiga Estação Colónia, foi verdadeiro empório colonial, quando do esplendor inteiro da região de colonização italiana, da qual era porta de acesso, rumo ao empuxo natural exercido por porto Alegre, função da Viação Fērrea do Rio Grande do Sul/VFRGS, ūnico e apropriado transporte de pessoas e cargas.

Claro está que a Vila, perdida esta função, adquiriu ou tra, economicamente menos vālida e socialmente adequada. Hoje, Camo bi residencial tem muito de dormitório e tende, cumprindo esta tare fa em relação ao seu espaço contīguo e prōximo, a uma completa ocu pação dos espaços vazios que ainda existem ao longo de seu territō rio excēntrico, por degolado, em razão de definições legais que con sideraram o Campus da UFSM, como pertencente ao 10 Distrito.

A grande partição do Distrito, é derivada naturalmente pe la proximidade da cidade, onde os espaços rurais esperam uma defin $\underline{i}$ ção de ocupação, ora estagnando a produção rural, ora presente com ausēncia de investimentos, pois sempre são considerados como espaço de destinação urbana, como de uso efêmero no tempo.

Em Camobi, o fato urbano agrava a ocupação rural, pois que, alēm da proximidade da sede, um nümero crescente de rodovias limi tam ou cortam seu mapa, incorporando potencialmente ao espaço jā ur banizado, extensas āreas, hoje jā contidas nos anēis rodoviārios, im potentes para resistir ao avanço da ocupação. Hā uma acentuada pré sença de propriedades, que variam entre 0 e 25 ha, na proporção de $52 \%$ do todo. 0 Grupo I, propriedades com atē 99 ha, significa $86,82 \%$ 
do universo. Todavia, função da presença de algumas propriedades do Grupo III, hã uma concentração de terras, nos pontos mais distantes da ārea fortemente urbanizada, principalmente à Sudeste do Distrito que tem interrompida a pulverização espacial, pela presença do Cam pus da UFSM, com àrea de 1.200 ha aproximadamente.

4! Distrito - SILVEIRA MARTINS

Com uma ärea total de $190 \mathrm{~km}^{2}$, representando $5,48 \%$ do to tal do Municipio, é um Distrito tipicamente colonial, com predominān cia das pequenas propriedades, em torno de 25 ha. Tal dimensão, coin cide com a partição original, quando do assentamento dos migrantes italianos, ali chegados em 1877. Era a propriedade básica e ainda hoje conhecida como "uma colónia".

A natural partição da "colōnia", função da prolîfera famỉ lia italiana, determinou a micro propriedade, hoje comum no Distri to, pois que, mais de $95 \%$ do conjunto, está enquadrado no Grupo I.

o Rebordo do Planalto, tal como descrito, é a domināncia da paisagem, onde o modelado atinge expressiva energia, em consequēn cia principalmente da drenagem densa, profunda e geradora de vales amplos e férteis. A cultura de subsistência ainda perdura, como ob jetivo secundário, em função dos usos e costumes arraigados, pois que de algumas décadas para cá, não foi capaz de inibir a "Batatinha" batata inglesa (solanum tuberosum), a cultura comercial por excelēn cia, sendo a única produção expressiva da região. A exigulidade do espaço e a prōpria topografia, altamente compartimentada, tornaram o Distrito verdadeira vertente de migrações internas. Hoje, o Dis trito não contēm sua população jovem, que busca comumente, outras āreas rurais do Estado e do Brasil, onde é possível expansão, ou bus ca quadros urbanos, principalmente por meio da atividade terciāria, onde o comércio desponta como principal.

50 Distrito - ARROIO DO SO

0 Distrito possui uma ärea total de $311 \mathrm{~km}^{2}$ e está assen tado sobre a Depressão Periférica, com presença nïtida dos comparti mentos das coxilhas e das "ilhas" aluvionais tipicas da Depressão. o predominio das formações geolōgicas é gerador dos solos arenosos, sendo que na porção Norte do Distrito, a deposição do Arroio Grande e do Vacacai-Mirim, ricos em sedimentos oriundos do planalto, geram terraços e vārzeas de significativa fertilidade e intensa ocupação, sendo esta porção a mais subdividida e mais agrícola do Distrito.

Jā o extremo Sul, drenado pelo Rio Vacacaỉ Grande, tendo como tributārio principal o Arenal, ambos cortando a Formação Santa Maria Inferior e Rosārio do Sul, gera vārzeas extensas e intensamen te rizicolas, em que pese a pobreza do solo arenoso recente. E pre cisamente neste compartimento misto, que encontram-se as maiores 
propriedades do Distrito.

Nesta porção do municipio de Santa Maria, o Grupo I (0-99 ha), representa $46,75 \%$ do total das propriedades. Fica pois eviden te, que a partição não é tão intensa como nos distritos mais próxi mos da sede, ou participantes significativamente do compartimento do Rebordo. E importante observar, que não só a vila sede do Distrito, como tambēm o domỉnio das propriedades menos expressivas em ārea (Grupo I), localizam-se na secção drenada pelo Vacacai-Mirim, que como antes referido, recebe como capeamento recente, sedimentos oriun dos do planalto. Há no domỉnio das coxilhas, cuja cota máxima não ultrapassa 100 metros de altitude, um predominio de propriedades maio res em direção à calha do Vacacaỉ Grande e Arroio Arenal, onde o Grupo III (500 - 1.999 ha), estā representado por 19,48\% do total das propriedades.

E importante observar que à Sudoeste da Vila sede, uma ārea em tudo igual ao compartimento (Superfície das Coxilhas), mas isola da do todo do Distrito pela presença do Arroio Arenal e limitada pe la rodovia pavimentada Santa Maria-São Sepé, mostra uma malha fundiā ria fortemente dividida, função principalmente do dito "Passo do Ver de" que, se no passado era vau de passagem de tropas, local de per noite pela presença de campos abrigados, tornou-se pela facilidade de acesso, ponto de veraneio grandemente concorrido e embrião de uma verdadeira mutilação das propriedades, gerando chācaras com atribı $\underline{i}$ ções de lazer.

0 uso intenso do solo de coxilhas, tem concorrido para um grande empobrecimento da paisagem, que hoje guarda pouco da fisiono mia original.

No espaço contíguo aos cursos d'água, os rios inexoravel mente perdem o emoldurado das matas galerias e nas vertentes e ci meiras das coxilhas, hā um empobrecimento célere, pelo uso agress vo de uma agricultura mais mecanizada sobre solo arenoso.

As propriedades maiores, representam uma atividade do $t \underline{i}$ po pastoril e conseguem as mais autēnticas paisagens, pelo tipo de uso que, se tambēm pode ser predador, não se iguala em agressão ao desarranjo que uma agricultura causa, sobre solos fisicamente frā ge is.

\section{Distrito - SÃO MARTINHO}

0 maior em superficie $\left(670 \mathrm{~km}^{2}\right)$, é também o de maior alti metria, onde a cota de 500 metros de altitude em relação ao nível do mar, é a mais significativa. O próprio Topo do Planalto, tem sua al titude média entre 400 e 500 metros, o que dá ao Distrito um domỉnio de terras altas, situando-se entre os compartimentos físicos do Rio Grande do Sul, de altitude média.

Tendo um embasamento vulcānico, como foi anteriormente 
descrito, pode nitidamente, ser dividido em dois sub-compartimentos designados de Topo do Planalto e Rebordo do Planalto.

0 Rebordo do Planalto, altamente cinzelado pelos rios e cörregos, é fortemente recortado e integra o todo numa proporção de aproximadamente $30 \%$ da área total. O trabalho dos rios, tanto da ba cia do Ibicuí-Mirim, quanto da bacia do Guassupi-Toropi, é o respon sāvel pela designação de serra que a região toma, onde a mais carac terística é a Serra de São Martinho. 0 Rebordo, que marca o fim do espaço vulcânico de rochas ācidas, fortemente recortado, è natural mente compartimentado. Por causa da drenagem profunda, é bem mais decomposto, pois oue o trabalho de entalhe fluvial ultrapassa os li mites da camada superior e atinge basalto e arenitos intertrap. A mata, função tambëm do nível hỉdrico mais rico, se instalou natural mente nas vertentes quase sempre ingremes nos terraços fluviais, ves tỉgios da migração dos cursos d'água e nos vales as vezes amplos, gerados pela expansão da drenagem na sua componente de erosão late ral. E neste ambiente fỉsico, perturbado e enērgico, que está a maior densidade populacional do 60 Distrito. A Vila de São Martinho, sede e aglomerados rurais, como: Boqueirão, Campinas, \$anto Inācio, Pe dreiras e São Miguel, são adensamentos populacionais que seguem a direção Leste/0este, marcados pelas fundas cicatrizes do Rebordo. Ai também, a intensa decomposição da rocha matriz, gerando solos mais fërteis, não passîveis de mecanização, deu origem a uma ocupação do tipo colonial, onde o trabalho familiar perdurou por anos, garan tindo uma malha fundiāria pulverizada, nos rincões e dobras da to pografia movimentada do Rebordo.

Lentamente, esta velha superficie, inicialmente ocupada por reduçào jesuîtica espanhola, foi sucumbindo. As florestas antes dominantes, tombaram na agricultura itinerante sobre cinzas. Os va les mais amplos e mais férteis, desnudos, deixaram de dar as respos tas mais vālidas dos primeiros momentos. As migrações se intensif caram e os espaços, dependendo da posição em relação ao centro urba no e do acesso ao mesmo, se reunificaram na proporção das distāncias e dificuldades viārias. E comum hoje, a pequena propriedade ao lon go de todo o acesso (rodovia que demanda à são Martinho), com incur sões nos vales mais importantes como é o caso do Ibicui-Mirim, man ter a mesma malha, ou ainda mais subdividida, porém com alterações profundas no objetivo de produção. Muitas vezes, simples chācaras de lazer das classes médias urbanas de menor poder económico e ape nas residuos da economia típica "colonial", pouco ou nada significa tivos.

Os nūcleos de colonização italiana, não conseguiram man ter nem sequer seus usos e costumes e se caboclizaram.

E nesta porção do 60 Distrito, que encontraremos $53,40 \%$ das propriedades de São Martinho, pertencentes ao Grupo I (0 - 99 ha). 
0 Topo do Planalto, domīnio do granōfiro, apresenta cam pos limpos sobre solos rasos e com intenso afloramento de rochas vul cânicas. E brusca a alteração da paisagem natural. Jā no primeiro quilōmetro alēm da vila de São Martinho, direção Norte, se descortị na um ondulado topogrāfico com sucessões de coxilhas, patamares e cerros arredondados, marcado por vegetação rasteira interrompida por capões isolados e mata galeria, identificadora da rede de drenagem bastante intensa, ora em direção Nordeste (bacia Ibicuỉ-Mirim), ora em direção Norte/Noroeste (bacia Guassupi-Toropi).

Historicamente, campos de invernagem são, ainda hoje, por serem campos duros (1itossolos), intensamente pastoris. Embora em algumas topografias mais brandas, existam lavouras comerciais de so ja, altamente mecanizadas, é a pecuāria de corte o forte econōmico do Topo do Planalto. E neste espaço ( $70 \%$ do todo do Distrito), que a malha fundiāria se mostra mais larga. As caracteristicas físicas do solo e topografia, ditam a atividade pecuāria. A atividade e a exploração possīvel, ditam a malha fundiāria. Nesta porção, 36,36\% das propriedades estão nos Grupos II e III, com áreas de 100 a 999 ha.

\section{7\% Distrito - BOCA DO MONTE}

Com uma ārea de $468 \mathrm{~km}^{2}$, ē um Distrito historicamente im portante, pois qưe no Passo dos Ferreiros, atual Ferreira, acontece a primeira fixação portuguesa, onde a Guarda de São Pedro, garantia posse nos incertos limites portugueses e espanhōis, ainda no ūltimo quartel do sēculo XVIII. O Distrito, afora uma pequena àrea ao Nor te da vila sede, que se configura como Rebordo, é dominantemente de coxilhas sedimentares da Depressão Perifērica. Algumas manchas alu vionais, ao longo da margem esquerda do Ibicui ao Norte, e do Ar roio Raimundo/Taquara à Sudeste, completam a paisagem tĩpica da Depressão. E exatamente nestas duas porções, Norte e Sudeste, que en contraremos a maior partição fundiāria do Distrito.

No Norte, ao longo da calha do Rio Ibicuỉ e marginal à via fērrea, na direção Noroeste, estão os maiores aglomerados, como a prōpria Vila da Boca do Monte, Canabarro, Cezar Pina e Caixa D'água.

No Sudeste, a drenagem do Taquara e do Raimundo, são res ponsáveis pelas colônias: Conceição, Raimundo e Toniolo, fruto de um adensamento populacional sobre solos mais férteis, por orgânicos, mais estāveis por topografia plana, criando não só condições agrỉco las mais favoráveis pela qualidade, mas principalmente mais duradou ras, tendo em vista as classes de solos, que permitem agressõesmais intensas.

A topografia, à partir da calha do Rio Ibicuí-Mirim, em di reção aos arroios Taquara e Raimundo, sofre alterações significat vas, variando de 125 metros (Ibicui-Mirim), passando por cotas de 
até 200 metros de altitude nas coxilhas divisoras e tendo suas cotas menos expressivas em altitude, na calha do Arroio Raimundo. Hā por tanto, um miolo de coxilhas, cuja predomināncia altimétrica, está entre as cotas de 150 e 200 metros, funcionando como divisor d'ägua das bacias do Uruguai e do Jacuí. Estas coxilhas, bastante defini das e com vertentes nitidas, são tipicas dos sedimentos das formaçoes Santa Maria Inferior e Rosário do Sul, geradoras de solos arenosos e de frágil estrutura física. E neste ambiente, que encontramos a malha fundiāria do Distrito, com pulverização da propriedade nas bor das Norte e Sudeste e propriedades maiores no centro coxilhado de sedimentos antigos.

Nos compartimentos descritos, margens aluvionais dos rios e ârroios, ao longo da ferrovia e da rodovia que demanda à cidade de São Pedro, estão $78 \%$ das propriedades rurais que classificamos co mo do Grupo I, ou seja, com ārea de 0 a 99 ha. 0 Grupo II, jā domī nio das propriedades maiores do que 99 ha e menores de 500 ha, repre sentam $21,1 \%$ do todo e juntamente com as do Grupo III, atē 999 ha, que representam $0,70 \%$ do todo, estão locadas predominantemente na Coxilna. Continua mantida a coerēncia entre os fatores físicos e hu manos (humanização por inserção de benfeitorias relevantes)e a quan tidade e dimensão das propriedades.

8Q Distrito - ITA $\bar{A} A$

Com ārea de $247 \mathrm{~km}^{2}$, é quase que totalmente um Distrito assentado sobre o Rebordo do Planalto. Apenas a porção terminal Norte, possui um pequeno trecho do Topo. Enérgico no relevo, apresenta so los rasos, litossölicos, com percentuais muito altos de superfícies com rochas afloradas. A vegetação tỉpica da transição entre Depres são e Planalto, era originalmente florestal. Hoje, com florestas re siduais nas encostas mais ingremes, tem no reflorestamento com eu caliptos, uma de suas formas de ocupação do espaço rural.

Alguns vales profundos, como o gerado pelo Taboão, arroio que entalhou o Baú (designação dada ao mais amplo e profundo vale do Distrito), viram assentadas aí famīlias italianas, que fazem até hoje, o contingente mais expressivo de Três Barras, uma das poucas manifestações aglomeradas, distante do eixo ferroviārio e rodoviārio, que corta o Distrito na direção Sul-Norte (Santa Maria-Jūlio de Cas tilhos). Em razão provavelmente da ferrovia e sobre este eixo, hou ve uma tentativa de ocupação, que historicamente repousou no desejo de consolidar uma colonização judaĩca na região, ainda hoje conhec $\underline{i}$ da por Fillipson. A vasta gleba, adquirida em 1902 pelo professor Léo Back, representante da Jewish Colonization Association (JCA), não resultou no atingimento do objetivo e de fragmentada comunitāria, pas sou a significar hoje 3 glebas de expressiva superficie, pois que, judeus remanescentes, incorporaram grande parte da "colónia" e outra 
foi adquirida pelo Estado, onde ainda agora, é mantida a Fazenda da Brigada Militar. Estas propriedades do Grupo IV, com mais de 1.000 ha, representam $1,9 \%$ do total das propriedades do Distrito, enquan to o Grupo I ( 0 - 99 ha), abrange $86,66 \%$ do todo das propriedades existentes no Distrito.

E importante observar, que a pulverização minifundiāria $\bar{e}$ tão grande, que o sub-grupo menor do que 25 ha, representa quase $50 \%$ da amostra.

0 Distrito hoje, função da BR 158, vê seu espaço fartamen te retalhado, pois que, em razão de seu clima de altitude e da topó grafia com feições serranas, tem atraỉdo crescentemente as popula ções urbanas mais aquinhoadas, que lá constroem uma residēncia de campo e tambēm as populações de menor poder aquisitivo, que vivem a paisagem "serrana", em clubes que se multiplicam dentro do espaço de transição, servido pelo acesso pavimentado da dita rodovia.

Os loteamentos em pequenas chācaras, oriundos de glebas pertencentes à Mitra Diocesana, quase todas medindo 0,25 ha, eviden ciam uma preocupação de lazer e não de produção e tem por objetivo a população da Santa Maria de classe mēdia que jā agrega a sî, os vicios das grandes cidades, sem contudo adquirir as virtudes que na turalmente deverão advir.

9 O Distrito - SANTA FLORA

Com $593 \mathrm{~km}^{2}$, segundo maior distrito de Santa Maria, Santa Flora é totalmente situada na Depressão Perifērica, predominantemen te de coxilhas.

o Arroio Sarandi, tributārio do Rio Arenal, fecha o $1 \mathrm{im} \underline{i}$ te Norte do Distrito e cria alguns bolsões de vārzeas aluvionais não tão ricos, pois que toda a bacia é originada e serpenteia, sobre os sedimentos da Formação Santa Maria e Rosārio do Sul. 0 Sul do Distri to, divisa do Municipio, é marcado pela presença dos pequenos tribu tārios que drenam o banhado Santa Catarina, pertencente ao vizinho Dilermando de Aguiar e pelo Rio Vacacaỉ Grande, que tambēm gera so los arenosos, embora topograficamente aplainados pela presença de vārzeas, que se alternam nas margens direita e esquerda.

As cotas de altitude, mais modestas em relação ao todo da ārea de depressão do Município, não ultrapassam 130 metros, sendo nesta linha altimētrica, que situa-se o divisor d'āgua, exatamente sobre o traçado da estrada principal, que dá acesso à sede, vila de Santa Flora. E nesta região com topografia de coxilhas, que encon traremos as colōnias Vacacaī (Santa Flora), Pinheiro, Grāpia e ou tros aglomerados, que no conjunto recebiam a designação de Colōnia Nova, visto terem sido criadas no segundo quartel deste século e abrigarem pequenos produtores, principalmente de agricultura dita do sēco e hoje tambēm do arroz. 
Desta forma, em contraste com outros segmentos do espaço rural de Santa Maria, não são os aluviões ou os rebordos recortados, que definem a maior quantidade de propriedades rurais, mas sim, a es trada e a intencional partição de sesmarias, em āreas antes flores tais ${ }^{2}$ da rica drenagem do Vacacaỉ, numa dorsal entre os riachos im portantes, como são a Sanga da Areia, Arroio Lavagem e da Cria.

As propriedades neste Distrito, encontram um equilibbrio de quantidades por grupos de dimensão. 0 Grupo I (0 - 99 ha), repre senta $35,22 \%$. 0 Grupo il, variando entre 100 e 500 ha, representa $36,36 \%$ e o Grupo III de 500 ha e mais, representa $28,40 \%$. E o Dis trito com menor número de propriedades do Municīpio.

\section{ANALISE DA PROPRIEDADE RURAL POR DIMENSAOO DA POSSE}

Utilizaremos nesta anālise, que busca verificar a varia ção nas dimensões do imōvel rural, o Coeficiente de Corrado Gini, que procura estabelecer a idéia de concentração, atravēs da amplitü de da variação entre " 0 " e "l".

Desta forma, Gini concebe que quando temos uma distribui ção uniforme, o indice é zero. Equivaleria a uma equidistribuição me ramente teōrica. Ao contrārio, quando toda uma determinada superfỉ cie, pertence a um ūnico proprietārio, o indice ē "l" e significa a māxima concentração. Atravēs desta variação, foi concebida uma clas sificação com valores gradativos, como segue:

- Concentração Nula

Nula a Fraca
Fraca a Média
Média a Forte
Forte a Muito Forte
Muito Forte a Absoluta

- de 0,000 a 0,100

- de 0,101 a 0,250

- de 0,251 a 0,500

- de 0,501 a 0,700

- de 0,701 a 0,900

- de 0,901 a 1,000

A validade deste coeficiente é discutível, não sob o pon to de vista de técnica, mas sim sobre o que realmente mostra. Ém de terminadas condições físicas, em determinado momento econōmico, es tāgio de desenvolvimento ou ainda em determinada sistemática de pró dução, poderemos aspirar, para um espaço agrārio, uma forte ou uma fraca concentração. Comumente, observamos na literatura algumas afir mações de pesquisadores, que concluem ser o Brasil um país de forte concentração de propriedade da terra, e por este indice explicam as graves crises no campo e cidade, que assolam todas as manifestações urbanas de porte médio à metrōpoles. Nesta tōnica, nasce o pregão das reformas ora urbanas, ora agrārias. Nesse conceito de concentra ção, surgem os planos de reforma, sem que exista uma anālise mais

2 As serrarias, hoje em processo lento de desativação, atestaram a presença da mata com madeiras ditas "de lei", ocupando todo o es paço agora jā completamente agrícola ou pastoril. 
acurada das razões e das condições físicas, econōmicas e histōricas que definem, alteram e dinamizam o perfil da malha fundiāria de um determinado espaço.

Inūmeras razões podem levar a população rural a buscar a cidade:

- melhoria de acesso campo-cidade, diminuindo considera velmente o tempo para alcançar o local de trabalho rural e assim, jus tificar a residência urbana;

- a perda, função da melhor acessibilidade ao centro urba no, do equipamento de lazer e de serviços que as sedes distritais detinham, fixando o homem rural e capacitando-o a satisfazer suas prioridades básicas, ainda nas proximidades da propriedade, local de trabalho. Neste particular, muito de responsabilidade cabe aos meios de comunicação, que de forma dinâmica, atraente, moderna e so fisticada, fizeram chegar a cidade ao homem do campo, com apelos ur banizantes irresistîveis;

- a modernização agrícola, gerada num meio desenvolvido, veio conflitar com a estabilizada cultura do homem rural, não fami liarizado com a modernidade consumista dos artefatos agrīcolas, in seridos de roldão no meio de produção e dirigidos em sua aquisição, pelos ōrgãos financiadores, os quais, por sua vez, cumpriam e cum prem o papel de multiplicadores da modernização, muito provavelmen te em beneficio da estrutura industrial, implantada no Brasil na me tade do sēculo atual.

Seguramente, muito do desarranjo na pequena produção, de ve-se ao incremento de mecanização, com tēcnicas e custos superió res à capacidade aquisitiva e de assimilação do homem rural das mé dias e pequenas propriedades.

A indūstria e a prōpria sociedade brasileira, nos quadros urbanos dos grandes centros, deve muito ao consumismo implantado no campo pelos agentes multiplicadores de necessidades criadas, mas in compatīveis com o momento econōmico e cultural do campo. E portanto este fator, provavelmente o grande responsāvel pela ausência cres cente do homem no campo, que frente a instabilidade ou ausēncia de polītica agrīcola, busca, mesmo no salärio mỉnimo ou nas tarefas gera doras do sub-emprego, uma independēncia das incertezas financeiras e de produção, que caracterizam o campo.

Inūmeras outras razões, fazem a inchação dos quadros urba nos brasileiros. As cidades não são capazes de assimilar esta cons tante migração que ocorre em estāgios, e evoluem sempre em direção às cidades maiores. E possīvel afirmar hoje, que nosso êxodo é muito mais das pequenas cidades para as capitais regionais e destas para as metrópoles, do que propriamente campo x cidade, em fluxo contí nuo. Evidentemente, quanto maior o fato urbano, mais possibilidades 
de trabalho, mesmo que eventuais, existirão, pois à prestação de ser viços, estão agregadas as tarefas de alta qualificação e as comple tamente não especializadas.

Será o Coeficiente de Gini, assim como tantos outros méto dos e técnicas, suficientemente claro e completo para definir a de cretação da dimensão da propriedade rural?

Mensurar a propriedade e caracterizá-la como pequena, mé dia ou grande e definī-la como concentrada ou não, é algo que requer estudo regional, onde os fatores mais significativos, além dos fis i cos, estão nos direcionamentos de uma política que hoje, como ontem, existe como "birutas" ao sabor dos ventos.

A variação do tamanho da propriedade, entre tantas variā veis, depende principalmente das seguintes:

Estāticas:

- caracterização física do espaço considerado (geopedoló gica);

- localização;

Dinâmicas:

- grau de modernização (insumos);

- estabilidade no objetivo de produção;

- produtividade;

- politica de fomento, estimulos e subsidios.

Considerando que as variāveis "estāticas" são independen tes, não hä política capaz de modificar a formação de litossolos, não há vontade política que altere a rocha mãe - geradora de solos po bres - como também é impossível, salvo em tempo histōrico considerá vel, melhorar a posição dos espaços em relação às concentrações ur banas de significação regional, são pois as definidoras da malha fun diāria de uma região.

Naturalmente e ao sabor dos mercados, a atividade ditada pelos componentes físicos, define-se como pastoril, agricola e/ou agropastoril e com o passar dos tempos, tendem as propriedades à par tição ou reagrupamento, a ponto de tornar possivel a ocupação produ tiva, sem paralelos com outras regiões, pois que o comportamento es pontâneo sempre foi e é ditado pela lei da sobrevivência.

Claro está que muitos fatores humanos de modernização, tem possibilitado gradativamente, uma diminuição de espaço com manuten ção de indice de renda compatível com a expectativa do produtor. Tó davia, não hā esta medida, pois que a instabilidade da atividade prí mária, não tem permitido que ela exista, com validade no tempo.

$\mathrm{Na}$ dependência da "política" agrāria vigente, os custos da modernização não podem ser assumidos pelo produtor, nem podem ser repassados ao consumidor. Gerada a instabilidade e o desconforto 
de produção, é imediatamente reativado o principio milenar da pru dência no espaço nacional, que mantém a estabilidade da produção, em que pese marque o espaço rural com fundas cicatrizes de avanços e recuos dentro dos princípios da modernização.

0 municipio de Santa Maria com $3.462 \mathrm{~km}^{2}$, è em tudo uma sintese do Rio Grande do Sul, pois que suas paisagens físicas repre sentam os dois mais importantes compartimentos do Estado (Planalto Meridional, dominio da rocha vulcânica, mais de $50 \%$ da superfície do todo estadual e Depressão Periférica).

Tanto no Planalto, quanto na Depressão, encontraremos a maior densidade demogrāfica, com vazios populacionais na fronteira leste, consequentemente as menores partições fundiārias e tambēm uma eleva da percentagem de propriedades de extensão bem acima da média. Tal fato, resulta naturalmente dos compartimentos físicos que determinam ainda, o nỉvel e modo de ocupação. Exemplo da afirmativa, $\bar{e}$ a sim ples comparação entre o solo raso da fronteira 0este, com rocha ma triz basāltica e vegetação rasteira nobre, imprōprio para agricultu ra de coxilhas e tornado pastoril com dominio da ovinocultura, com a calha do Jacuī, trecho médio e inferior, policultor sobre aluviões fērteis que sugerem, permitem e respondem por uma agricultura diver sificada.

Também Santa Maria, guardada a relatividade dimensional,apre senta a mesma dicotomia de paisagens e assim, função dos ambientes físicos, teremos a malha fundiāria coerente com a tradição, a poten cialidade e a possibilidade de uso da superficie fisica abrangida.

Nos últimos quinze anos, cresceu o número de propriedades no municipio de Santa Maria. Isto equivale dizer, há um maior núme ro de proprietārios, pessoas físicas, no espaço agrário de Santa Ma ria. No entanto, em que pese uma maior partição na posse da terra, a população rural na última década decresceu 5.459 habitantes, em favor do quadro urbano. Hoje, a cidade, seguindo o rumo da população brasileira, tende ao engrossamento da população urbana e jā possui $85,12 \%$ de residentes em aglomerados (sedes e vilas).

Considerando o espaço do municipio de Santa Maria, pode mos afirmar que a estrutura fundiāria sofreu e sofre alterações na sua acomodação, basicamente fundamentada na qualidade geopedológica e de localização dos espaços dentro do todo físico e em relação ao centro urbano.

0 Coeficiente de Gini em Santa Maria, corresponde a 0.7164 , e é classificado como FORTE, o que equivale dizer, tende a concen tração MUITO FORTE. Posto assim, imaginamos na frieza deste indice, uma terra detida por um pequeno número de proprietários. No entanto, nossa anālise anterior, provou que o indice de pulverização da pro priedade è grande e crescente. Todavia,algumas propriedades classificadas 
como grandes e que determinam a posse percentual de grande porção do todo, situam-se exatamente sobre compartimentos fisicos onde a atividade agrỉcola é impossível ou não responde satisfatoriamente, sem ocasionar danos significativos ao arranjo optimizāvel do espaço. Areas com solos rasos ou afloramentos de rochas extensas, bem como āreas de solos arenosos sobre coxilhas, não tem admitido a agricul tura. Tal fato, não aconselha a partição, pois que, enquanto uma pe quena porção de espaço agrïcola racionalmente produzido permite so brevivência digna, a mesma ārea com atividade pastoril, cria subvi da insuportável, frente a magnitude do patrimōnio.

Considerando o Coeficiente de Gini, não para o todo do Mu nicipio, mas sim, para cada parcela distrital, o comportamento des te indicador de concentração se altera significativamente. Senão ve jamos:

\section{Distrito - SANTA MARIA}

Coeficiente de Gini: 0.6928 = Concentração MEDIA a FORTE.

Como ficou visto, este Distrito, em razào de conter a se de urbana, é especialmente pulverizado, pois que $99,66 \%$ das proprie dades pertencem ao Grupo I (0 - 99 ha). Todavia, uma ünica proprie dade da amostra, enquadrada fora do grupo dos menores de 99 hectares, joga o percentual de ārea detida individualmente, para um coeficien te de concentração com tendēncia a FORTE.

A situação residual da propriedade maior (pertencente ao Grupo II - atē 499 ha), no Distrito altamente pulverizado, mascara a eficiência indicativa do Coeficiente de Gini (Base Aérea de Santa Maria). Colocado como verdade absoluta, indica uma forte concentra ção em ārea de excessiva partição, até sob o ponto de vista produti vo, preocupante.

\section{Distmito - DILERMANDO DE AGUIAR}

Coeficiente de Gini: 0.6554 = Concentração MEDIA a FORTE.

E realmente onde pequeno nūmero de proprietārios detém uma porção significativa do Distrito, pois que o Grupo IV (propriedades maiores de $2.000 \mathrm{ha})$, representa $37.07 \%$ da ārea do Distrito. Cabe pois, analisarmos as razões da supremacia significativa da proprie dade de maiores dimensões neste espaço. A principal, repousa na cons tituição física do solo e no isolamento por tempo bastante grande, nos confins de Santa Maria-Sul-0este, divisa com São Gabriel e Cace qui. Dificuldades até hoje em algumas porções insuperāveis, geradas pela precariedade das estradas sobre solo arenos.o.

30 Distrito - CAMOBI

Apresenta tambēm um coeficiente de concentração entre ME DIO e FORTE, tendendo para MEDIO: 0.5860 .

Algumas propriedades do Grupo II e III, são responsāveis 
por esta aparente concentração. O Grupo III (propriedades com atē 499 ha), é o limite da posse maior e significa $12,5 \%$ da ārea total do Distrito. Seu mapa sofrendo estrangulamento - pela presença do Campus da UFSM - tem, na porção Nordeste, uma distância e um isola mento maior, da influência do quadro urbano.

4 Q Distrito - SILVEIRA MARTINS

Distrito de economia colonial, densamente povoado. E 0 menor indice de concentração do Município. O coeficiente 0.4459 , clas sificando o Distrito como de concentração FRACA a MEDIA, palidamen te confirma a grande exigulidade de espaço rural, que além de grande mente partido, situa-se no Rebordo do Planalto altamente modelado pe los cursos d'água e completamente agrícola.

Desde a origem da ocupação, nasceu o espaço de produção mi nifundiāria e o parcelamento consequente é o grande gerador das mi grações - jā referidas - na direção, ora de novos e mais amplos am bientes rurais, ora aos quadros urbanos.

0 coeficiente identificando como média concentração, não indica a adequação, pois que, embora o Distrito busque emancipação, não se caracterizam nem por destaque de produção - exceção à "bata tinha" - nem por qualidade de vida melhor que os demais espaços ru rais.

50 Distrito - ARROIO DO SO

0 coeficiente 0.5834 , indica novamente uma concentração MEDIA a FORTE sobre um espaço com predominância de atividade rizíco la e pastoril. Ambas atividades requerentes de espaços amplos - e que tendem a estabilidade, pois que o aspecto de respostas, exige um nível econōmico compatīvel com o capital e a velocidade de produ ção. Os solos arenosos da drenagem do arenal, no caso do arroz, não autorizam pequenos espaços de produção, pois que a produtividade ba xa, exige āreas mais amplas justificadoras de assimilação dos gas tos minimos que a cultura requer.

60 Distrito - SÃO MARTINHO

Localizado no Topo do Planalto, com dominio das proprieda des maiores e no Rebordo, dominio das propriedades menores, tem n $\underline{\vec{i}}$ tida diferença na forma de ocupação: pecuāria e agricultura comercial no Topo, pequena produção e lazer no Rebordo.

o Coeficiente de Gini marca 0.6652 - MEDIO a FORTE e tem seu embasamento na condição de solos rasos e na topografia enērgica, marcando nitidamente o tipo de ocupação produtiva dos espaços.

A pecuária de grande porte é realizada nos espaços amplos do Planalto e por algum tempo, ainda perdurará como forma racional de ocupação, pois que os solos ácidos e rasos e os afloramentos ro chosos, não aconselham uma exploração agrỉcola intensa e só em pequenas 
ilhas, autorizam uma pecuária sustentada na ocupação da terra como geradora de alimentos cultivados (pastagens artificiais) para a bo vinocultura. Todavia, esta prática tem se mostrado inadequada, fren te ao conflito custo de produção, repasse ao consumidor e baixo po der aquisitivo da população.

7\% Distrito - BOCA DO MONTE

O Coeficiente de Gini 0.5465, indica Boca do Monte como de concentração MEDIA a FORTE, com tendēncia a MEDIA, função principal mente da forma de ocupação ao longo de uma ferrovia, pioneiro cam $\underline{i}$ nho de transporte pesado.

0 solo fisicamente frăgil, não permite agressões intensas, salvo com investimentos incompatíveis com o atual estágio econômico brasileiro. Esta situação determina a ocupação pastoril sobre coxi Ihas e adensamentos populacionais agricolas, nos aluviões do Ibicuỉ Mirim e na drenagem do Sul. E um Distrito de pequena expressão eco nômica, pois a carência de espaço pastoril, não dinamiza melhorias significativas, função da descapitalização crescente do homem rural, apertado neste espaço frágil, que tende a uma partição insustentável, determinadora de resposta financeira, incapaz de manter niveis de produção compatíveis com modernização crescente.

8? Distrito - ITAARA

o Coeficiente de Gini, aplicado à malha fundiāria de Itaāra, aponta uma concentração igual a 0.7204 - FORTE a MUITO FORTE.

Representa a mais alta concentração de terra no Municīpio, recaindo exatamente sobre o mais repartido Distrito do todo.

E Itaāra, como ficou demonstrado, o dominio do Rebordo/Tran sição e consequentemente da pequena propriedade. As propriedades com ārea de 0 a 99 ha, representam $86,66 \%$ do universo e detēm $28,64 \%$ da ārea, enquanto as propriedades do Grupo IV (maiores de 1.000 ha), re presentam $1.9 \%$ das propriedades, abarcando $25,59 \%$ da ārea total. Evi dente que a técnica do Coeficiente de Gini mostra esta forte concen tração, sem contudo salientar que são propriedades situadas no tre cho final do Rebordo, ūltima porção da transição jā quase Topo, on de o solo, por raso e litossolo, não oportunizou uma atividade agri cola mais intensa, como pioneiramente ocorreu no trecho imediatamen te anterior, hoje fortemente ocupado pelo lazer, com tendência a va lorização urbana. Algumas razões histōricas (colonização judaĩca), remanescem e permitem a existência destas propriedades maiores, que determinam o paradoxal coeficiente, indicador de FORTE concentração - a maior no Municipio - sobre o espaço mais pulverizado do todo.

9O Distrito - SANTA FLORA

0 coeficiente 0.5996 , indica concentração MEDIA a FORTE. A forte colonização na porção central do Distrito - sobre um nítido 
e rico divisor d'āgua consegue a tendência à concentração média, mui to embora a dominância do espaço de coxilhas, principalmente nas ver tentes da bacia do Vacacaỉ, indique solos pobres e arenosos, onde as propriedades maiores buscam na pecuāria, a atividade adequada, e concentrem $42,82 \%$ da ārea.

Numa anālise isolada, podemos afirmar ser um espaço em

franca evolução de produção, com intensificação da agricultura nas áreas passíveis de respostas economicamente vālidas, buscando a in tegração com a pecuāria ainda dominante.

CONCLUSOES

0 municīpio de Santa Maria, possui um nūmero exagerado e crescente de pequenas propriedades (incremento de $+8 \%$ nos ūltimos 15 anos), e tende à partição das propriedades ditas grandes, num ritmo acelerado (redução de quase $5 \%$ nos ūitimos 15 anos).

A pulverização da propriedade no anel mais prōximo da cí dade, tende à formação de espaços rur-urbanos, aguardando, estagna dos, a valorização urbana.

A periferia recebe estímulos de urbanização na proporção do aumento da malha viāria, inicialmente e por planejamento, de tan gência.

A propriedade rural se pulveriza em dimensão e a descapi talização do produtor não tem permitido agregação - afirmativa vāl $\underline{j}$ da para todas as dimensões (grupos de estabelecimentos).

Hā uma forte tendência à aquisição de terras por parte de empresas urbanas, cujos proprietārios novos, possuiam velhas origens rurais e frente a disponibilidade de capital - ausente no campo aplicam seus excedentes no ambiente rural e com isto usufruemdaatual polîtica fiscal-tributāria.

Há uma vocação, nas āreas topograficamente mais movimenta das e de altitude expressiva (em relação ao todo), à formação de și tios de lazer, que na dependência das condições de acesso, atraem clientela de maior e menor poder aquisitivo (como sempre a seleção se dá pelos $(z \$)$.

As āreas vocacionadas para a agricultura, tendem a uma par tição mais acentuada. As āreas com maior pobreza de solo, maior com plexidade dos compartimentos (classe de solo inadequado) ou solos rasos, por rocha matriz aflorante, tendem à pecuāria de grande por te e por esta razão mantém um espaço maior.

Considerando o Coeficiente de Gini, como indicador de con centração, podemos afirmar que Santa Maria possui FORTE a MUITO FOR TE concentração (0.7164). Todavia, retirado da anālise o DISTRITO DE ITAARA, passaríamos a uma concentração de MEDIA a FORTE, com nĩ tida tendēncia à MEDIA.

Abandonada a idéia de grandeza, onde os termos pequena, média 
e grande, não identificam absolutamente nada na realidade local, pois o referencial não existe nem para o produtor, poderíamos ficar com outra idéia de espaço, aỉ sim completamente palpāvel, e dizer a maior ou a menor propriedade. Todavia, o que se deve buscar, è a função do espaço e não a dimensão. Na função, tecnicamente deveria ser medido o potencial de determinada área e principalmente a capa cidade de contenção dentro dos limites mỉnimos de aspiração de cres cimento do homem, a fim de garantir o estimulo, fixador do produtor na atividade. Esta função, medidos todos os componentes: físicos, de localização, de acesso, de produção, de produtividade, de compa tibilidade com o mercado, de coeréncia com a "politica nacional", de equipamento estrutural minimo, de bem estar social (inclui lazer), de capacidade de endividamento, de nîvel técnico adequado aos cus tos e ao mercado consumidor, chegariamos realmente a funcionalidade de cada espaço "produzido", como resultante de um momento ou de um estāgio da vida de cada região. Alguns indicadores, por dinâmicos, sofrem variações constantes, mas na dependência das possibilidades do consumidor, razão ūltima da produção, podem ou não ser adotados.

Até a simples e básica melhoria das condições de fertilí dade do solo, anos hā que não ficam autorizadas, pois oneram de tal forma, que mesmo a resposta mais positiva, não resulta em saldo fa vorável ao produtor e gera descrença e desestímulo tanto maior, quan to maior a dependência e a dificuldade de mudanças de objetivo de produção - quase sempre calcada no pressuposto fundamental que è ainda a quantidade de espaço disponivel.

Desta forma, nossa preocupação é afirmar que, de certa ma neira, na dependência da localização, do acesso e das condições fí sicas, teremos necessidade de espaços agrārios de produção de fraca ou de forte concentração.

Com base nestas observações, que não esgotam 0 assunto, somos inclinados a concluir que o Coeficiente de Gini, aplicado no espaço do município de Santa Maria, é um dado que indica FORTE CON CENTRAÇAO, mas não indica se esta concentração é desejāvel ou não.

Nos espaços do Topo do Planalto e Coxilhas da Depressão, onde dominam as propriedades maiores, resulta uma malha mais adequa da, no momento econômico que vivemos, conseqüentemente propriedades mais convenientes funcionalmente para o espaço em apreço, sendo sig nificativamente mais preocupantes a pulverização dos espaços contî guos, que perdem a essência do objetivo primārio, frente a sucessão de crises por que passa o produtor, absorvedor terminal das crises globais.

\section{BIBLIOGRAFIA CONSULTADA}

BELEM, J. História do municipio de Santa Maria. Porto Alegre, Sel bach, 1933. 
BERNARDES, S.A.C. Anālise da estrutura fundiāria do Rio Grande do Sul. In: I Seminário Santamariense de Geografia. 29-33, 1972.

BORTOLUZzi, C.A. Contribuição à geologia da região de Santa Maria, Rio Grande do Sul, Brasil, Pesquisas, Porto Alegre, 4(1): 7-86, 1974 .

COHEN, V.R. de A. A Imigração Judaica no Rio Grande do Sul. In: RS: Im $\underline{i}$ grą̧ão e Colonizą̧ão, Sērie Documenta 4, Porto Alegre, RS, Merca do Aberto, 67-90, 1980.

GERARDI, L.H. de O. \& SILVA, B.C.N. Quantificą̧ão em Geografia. São Paulo, Difel, 1981.

PAZERA Jr., E. Cadastro fundiārio de Salgado de São Fēlix (PB): Uma abordagem de Geografia Quantitativa. Geonordeste, Aracaju, 2:69$73,1985$.

SARTORi, P.L.P.; MACiel Filho, C.l. \& MenegotTo, E. Contribuição ao estudo das rochas vulcânicas da Bacia do Paranā na região de San ta Maria, RS. Rev. Bras. de Geociências, São Paulo, 3(5):141-159, 1975.

Recebido em dezembro, 1988; aceito em dezembro, 1988. 
